\title{
Kandungan Pencemar Detejen Dan Kualitas Air Di Perairan Muara Sungai Tapak, Semarang
}

\author{
Nurindahsari Niken Larasati ${ }^{1 *}$, Sri Yulina Wulandari ${ }^{1}$, Lilik Maslukah $^{1}$, Muhammad Zainuri $^{1}$ \\ dan Kunarso ${ }^{1}$
}

\author{
${ }^{1}$ Departemen Oseanografi, Jurusan Ilmu Kelautan Fakultas Perikanan dan Ilmu Kelautan \\ Jl. Prof. H. Sudarto, SH Tembalang, Telp/fax (024) 7474698 Semarang 50275 \\ *Email: *nurindahsariniken@students.undip.ac.id
}

\begin{abstract}
Abstrak
Perairan Muara Sungai Tapak, Semarang merupakan saluran sungai yang melalui kawasan padat penduduk. Seiring dengan meningkatnya pertumbuhan penduduk, kebutuhan deterjen sebagai bahan pembersih cenderung meningkat, hal ini diketahui dari meningkatnya usaha laundry. Limbah dari kegiatan laundry dapat menyebabkan pencemaran. Surfaktan pada deterjen dapat menimbulkan busa yang mengganggu pemandangan serta mengganggu proses fotosintentesis. Senyawa fosfat dalam deterjen di perairan juga dapat menyebabkan eutrofikasi. Penelitian dilakukan pada bulan Oktober 2019 di Perairan Muara Sungai Tapak Semarang, untuk mengetahui kandungan pencemar deterjen, Indeks Kualitas Air (IKA), Indeks Pencemaran (IP) dan kualitas perairan. Metode yang digunakan adalah metode survei dengan teknik purposive sampling. Lokasi sampling terdapat 8 stasiun dengan 3 titik (badan sungai, muara dan laut). Pengambilan sampel menggunakan botol sampel yang kemudian dibawa ke Balai Besar Teknologi Pencegahan Pencemaran Industri (BBTPPI) untuk dianalisis konsentrasi deterjennya dengan metode MBAS. Konsentrasi deterjen di stasiun 1 dan 2 sebesar 0,026 mg/L dan $0,017 \mathrm{mg} /$. Adapun konsentrasi deterjen di stasiun 3 sampai 8 sebesar <0,010 mg/L, karena konsentrasi deterjen yang terlalu kecil, sehingga tidak dapat terdeteksi oleh alat yang digunakan, yaitu spektrofotometer. Indeks Kualitas Air (IKA) di Perairan Muara Sungai Tapak Semarang berkisar antara nilai 1,627 - 1,710 dan Indek Pencemaran (IP) berkisar antara nilai 1,787 - 1,975 yang termasuk tercemar ringan. Kualitas air di Perairan Muara Sungai Tapak masih dalam kisaran baik bagi vegetasi mangrove. Dapat disimpulkan bahwa, konsentrasi deterjen belum melebihi baku mutu yaitu $0,2 \mathrm{mg} / \mathrm{L}$.
\end{abstract}

Kata Kunci : Deterjen, Indeks Kualitas Air, Indeks Pencemaran, Perairan Muara Sungai Tapak Semarang

\begin{abstract}
Tapak waters of estuary river, Semarang is the channel of a river which through a highly populated area. Along with the increasing population growth, the need for detergents as cleaning agents tend to be increased, it is known from a growing laundry business. Waste from laundry activities can cause pollution. Surfactants in detergents can caused foam that disturb the landscape and disturb the process of photosyntesis. Phosphate compounds in detergents in waterways can also cause eutrophication. The research conducted in October 2019 in the Tapak waters of estuary river, Semarang, to determined the content of contaminants of detergent, Water Quality Index (IKA), the Pollution Index (IP) and the quality of the waters. The method used is survey method with purposive sampling technique. There are 8 stations of sampling locations with 3 points (rivers, estuaries and the sea). The sampling was using a bottle sample which is then brought to the Balai Besar Teknologi Pencegah Pencemar Industri (BBTPPI) to be analyzed the concentration of detergent by MBAS method. The concentration of detergent in stations 1 and 2 were $0,026 \mathrm{mg} / \mathrm{L}$ and $0,017 \mathrm{mg} / \mathrm{L}$. While the concentration of detergent in the stations 3 to 8 were $<0,010 \mathrm{mg} / \mathrm{L}$, caused the amount of the detergent concentration was too small, so it can't be detected by the instrument, which was spektrofotometer. Water Quality Index (IKA) in the Tapak waters of estuary river, Semarang ranged between the value of 1,627 - 1,710 and The Index of Pollution (IP) ranged between the value of 1,787 - 1,975 which included a light polluted. Water quality in the Tapak waters of estuary river were still within the range of good water quality for the mangrove vegetation. Based on the research results, it can be concluded that, the concentration of the detergent has not exceeded the quality standard i.e. $0,2 \mathrm{mg} / \mathrm{L}$.
\end{abstract}

Keywords : Detergent, Water Quality Index, Pollution Index, Tapak Waters of Estuary River Semarang 


\section{PENDAHULUAN}

Pencemaran merupakan sebuah peristiwa masuknya suatu zat atau senyawa yang berasal dari luar lingkungan ke dalam suatu lingkungan secara sengaja maupun tidak sengaja. Pencemaran di air dapat menyebabkan kondisi air yang tadinya normal menjadi tidak normal, sehingga perubahan fisik, kimia maupun biologi ini dapat membahayakan kehidupan bagi makhluk hidup (Situmorang, 2017).

Sumber pencemaran di perairan dapat berasal dari limbah domestik. Limbah domestik adalah limbah yang berasal dari kegiatan sehari-hari rumah tangga, seperti kegiatan mencuci yang menggunakan deterjen dan pewangi. Limbah domestik dapat dibagi menjadi dua, yaitu limbah organik seperti sisa sayuran dan makanan serta limbah anorganik seperti plastik, bahan-bahan kimia yang berasal dari penggunaan deterjen, sampo maupun sabun. Seiring dengan meningkatnya pertumbuhan penduduk, kebutuhan deterjen sebagai bahan pembersih cenderung meningkat. Hal ini diketahui dengan semakin meningkatnya usaha laundry di masyarakat. Limbah dari kegiatan laundry yang mengandung deterjen perlu dilakukan pengolahan terlebih dahulu sebelum dibuang, contohnya dengan menggunakan biofilter berupa tanaman air (Suastuti et al., 2015). Biofilter yang digunakan merupakan tanaman kelompok mikroorganisme rhizosfer yang mampu melakukan penguraian terhadap benda-benda organik atau anorganik yang terdapat pada limbah (Waluyo, 2005). Apabila limbah dari kegiatan laundry yang mengandung deterjen tidak diolah terlebih dahulu, deterjen akan memasuki sungai dan terakumulasi di laut dan menyebabkan pencemaran. Surfaktan pada deterjen dalam jumlah tertentu dapat menimbulkan busa yang mengganggu pemandangan serta menutupi permukaan perairan dan berdampak pada proses difusi oksigen dari udara yang menjadi lambat, sehingga kadar oksigen yang terlarut pada air menjadi sedikit dan mengganggu kehidupan organisme perairan, terutama pada organ ikan, seperti yang terjadi di Perairan Depapre, Provinsi Papua yang merupakan daerah pariwisata, pemukiman dan pelabuhan (Tanjung et al., 2019). Senyawa fosfat dalam deterjen di perairan dapat menyebabkan eutrofikasi, karena dapat menyebabkan tanaman perairan menjadi subur dan pertumbuhan alga menjadi lebih tinggi, yang apabila melebihi batas dapat menyebabkan blooming. Selain berasal dari limbah domestik, pencemaran di perairan dapat berasal dari limbah non domestik. (Yuliani et al., 2015).

Deterjen sintetis memiliki sifat yang dapat membersihkan dengan baik dan tidak membentuk endapan dengan ion-ion. Namun, deterjen memiliki bahan aktif yang disebut dengan surfaktan yaitu bahan aktif dari deterjen yang dapat menurunkan kualitas air (Situmorang, 2017).

Perairan muara Sungai Tapak Semarang adalah saluran drainase yang terletak di daerah padat penduduk (Supriyadi, 2008). Perairan muara Sungai Tapak Semarang juga merupakan salah satu saluran akhir dari sungai-sungai lain, dengan kata lain, semua yang terangkut oleh sungai akan berakhir dan terakumulasi di perairan muara Sungai Tapak yang pada akhirnya akan terangkut menuju laut. Tingginya jumlah dan aktivitas penduduk, menyebabkan perairan muara Sungai Tapak Semarang mendapatkan masukkan limbah, terutama limbah yang diperoleh dari aktivitas penduduk, yaitu deterjen (Oktaviani et al., 2015). Pemasukkan deterjen juga berasal dari kegiatan industri yang berada di sekitar perairan, seperti PT Golden Mayaran, PT Khasrisma Klasik, PT Marie Albert Indonesia, PT Karya Cipta Nyata Wisesa, PT Gas Industri dan sebagainya. Pemasukkan deterjen ke perairan dapat menurunkan kualitas perairan karena dapat menyebabkan pencemaran di sungai dan laut, seperti penurunan kadar oksigen terlarut perairan yang mengganggu kehidupan organisme perairan serta menyebabkan perairan menjadi bau dan keruh (Yuliani et al., 2015). Menurut Keputusan Menteri Lingkungan Hidup 51 Tahun 1995 Tentang Baku Mutu Limbah Cair Industri, kandungan deterjen atau Methyil Blue Active Benzene (MBAS) memiliki kadar maksimum 5 (mg/l).

\section{MATERI DAN METODE Materi Penelitian}

Materi yang digunakan dalam penelitian ini terdiri dari data primer dan sekunder. Data primer merupakan data utama yang digunakan dalam penelitian dan diperoleh secara langsung pada saat pengambilan sampel berlangsung. Data primer yang digunakan adalah sampel air yang diambil pada hari Senin, 28 Oktober 2019. Data sekunder merupakan data pelengkap yang digunakan dalam 
penelitian. Data sekunder yang digunakan dalan penelitian ini adalah kualitas air (suhu, salinitas, kecerahan, $\mathrm{pH}$, dan oksigen terlarut), data arus, data angin dan Peta Rupa Bumi Indonesia.

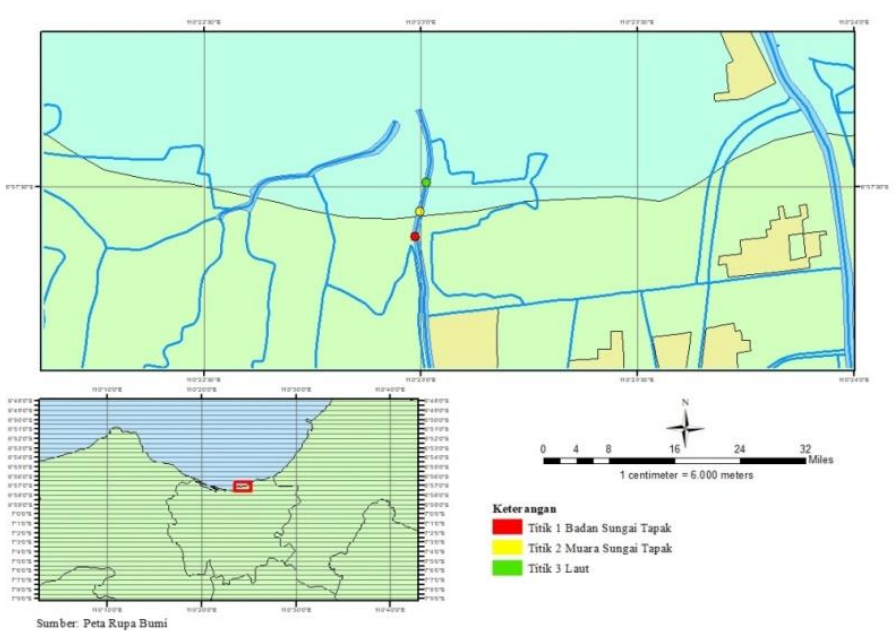

Gambar 1. Lokasi Penelitian

\section{Metode Penelitian}

Metode yang digunakan dalam penelitian adalah metode survei yang bersifat deskriptif kuantitatif. Pada umumnya metode survei dilakukan untuk memperoleh fakta-fakta dari gejala yang ada dan mendapatkan data yang faktual atau sesuai lapangan. Dapat dikatakan bahwa metode survei merupakan metode yang digunakan untuk kumpulan-kumpulan objek dengan asumsi bahwa objek yang diteliti telah mewakili populasi yang diamati (Iqbal, 2004 dalam Sumartini et al., 2013).

\section{Metode Pengukuran Lapangan}

Titik lokasi sampling ditentukan dengan menggunakan GPS. Pengambilan sampel menggunakan metode purposive sampling yaitu sampel diambil untuk diteliti kandungan deterjennya di Balai Besar Teknologi Pencegah Pencemaran Industri (BBTPPI). Lokasi sampling dilakukan di muara Sungai Tapak dengan pengambilan data di tiga lokasi, yaitu badan sungai, muara sungai dan laut dengan jarak 500 meter. Pengambilan data dilakukan di delapan stasiun, yaitu stasiun 1, dan 2 di badan sungai. Sedangkan stasiun 3, 4, 5 dan 6 di muara sungai serta stasiun 7 dan 8 di laut.

Pengambilan sampel dilakukan di muara Sungai Tapak dengan menggunakan ember yang kemudian di simpan di botol sampel 1,5 L lalu sampel diberi keterangan menggunakan label meliputi nomor lokasi, hari, tanggal dan jam pengambilan sampel. Setelah itu sampel dibawa ke Balai Besar Teknologi Pencegah Pencemaran Industri (BBTPPI) untuk dianalisis kandungan deterjennya.

Data sekunder seperti kualitas air (suhu, kecerahan, salinitas, $\mathrm{pH}$ dan DO), data arus dan data angin juga diambil bersamaan dengan pengambilan sampel air. Data kualitas air seperti suhu diambil dengan menggunakan termometer sedangkan $\mathrm{pH}$ diambil dengan menggunakan $\mathrm{pH}$ meter. Data salinitas diambil dengan menggunakan Hand Refraktometer serta data DO diambil dengan menggunakan DO meter. Data kecerahan perairan diambil dengan menggunakan secchi disk. Dan data parameter oseanografi seperti arus diambil dengan menggunakan flow meter, sedangkan untuk data angin diambil dengan menggunakan anemometer dan untuk mengetahui arah anginnya menggunakan kompas tembak.

\section{Metode Pengolahan Data}

Perhitungan konsentrasi deterjen dilakukan di Balai Besar Teknologi Pencegah Pencemaran Industri (BBTPPI). Metode yang digunakan dalam pengujian analisis kandungan deterjen adalah APHA-AWWA-WEF-5540-C-2005. Metode ini menyebabkan surfaktan anionik bereaksi dengan metilen blue sehingga dapat membentuk pasangan ion yang berwarna biru dan dapat larut dalam pelarut 
organik. Intensitas warna biru yang dihasilkan diukur dengan menggunakan spektrofotometer dengan panjang gelombang $652 \mathrm{~nm}$. Serapan yang terukur setara dengan kadar surfaktan anionik.

Perhitungan Indeks Kualitas Air (IKA) dilakukan dengan menggunakan persamaan Altansukh dan Davaa (2011):

$$
\mathrm{IKA}=\frac{\Sigma\left[\frac{\mathrm{Ci}}{\mathrm{PIi}}\right]}{\mathrm{n}}
$$

Dimana :

IKA : Indeks Kualitas Air

$\mathrm{Ci} \quad$ : Konsentrasi peubah mutu air ke-i

PIi : Baku mutu air yang diperbolehkan untuk peubah mutu air ke-i

$\mathrm{n} \quad$ : Jumlah peubah mutu air yang diamati

Perhitungan Indek Pencemaran (IP) dilakukan sesuai dengan Keputusan Menteri Lingkungan Hidup No. 115 Tahun 2003 Tentang Status Mutu Air, dengan rumus:

$$
P i j=\frac{\left(\frac{C i x}{L i j}\right) M+\left(\frac{C i x}{L i j}\right) R}{2}
$$

Apabila nilai $\left(\frac{\mathrm{Cix}}{\mathrm{Lij}}\right)>1$, maka menggunakan persamaan $\left(\frac{\mathrm{Cix}}{\mathrm{Lij}}\right)$ baru, yaitu:

Dimana :

$$
\left(\frac{\mathrm{Cix}}{\mathrm{Lij}}\right) \text { baru }=1,0+5 \log \left(\frac{\mathrm{Cix}}{\mathrm{Lij}}\right)
$$

Lij : konsentrasi parameter kualitas air yang dicantumkan dalam baku mutu peruntukan air (j).

$\mathrm{Ci} \quad$ : konsentrasi parameter kualitas air hasil survei

Pij $\quad$ : Indeks pencemaran bagi peruntukan (j)

$(\mathrm{Ci} / \mathrm{Lij}) \mathrm{R} \quad$ : Nilai rata-rata dari jumlah konsentrasi parameter yang diuji

$(\mathrm{Ci} / \mathrm{Lij}) \mathrm{M} \quad$ : Nilai maksimal dari hasil pembagian nilai konsentrasi dengan baku mutu

\section{HASIL DAN PEMBAHASAN}

\section{A. Kualitas Perairan Muara Sungai Tapak Semarang}

Data lapangan yang diambil meliputi kualitas perairan yang meliputi salinitas, DO, $\mathrm{pH}$, suhu dan kecerahan serta data faktor oseanografi yang meliputi kecepatan angin, arah angin dan kecepatan arus. Data kualitas perairan tersaji pada Tabel 1.

Tabel 1. menyajikan mengenai kondisi kualitas Perairan Muara Tapak, Semarang pada setiap stasiun yang digunakan atau diamati. Stasiun 1 dan 2 berada di badan sungai, stasiun 3, 4, 5 dan 6 berada di muara sungai serta stasiun 7 dan 8 berada di laut. Rata-rata nilai salinitas di Perairan Muara Sungai Tapak Semarang berkisar anatara $30 \mathrm{ppt}-40 \mathrm{ppt}$, sedangkan nilai DO rata-rata di Perairan Muara Sungai Tapak Semarang berkisar antara 8,310 mg/L - 9,260 mg/L. Rata-rata nilai pH di Perairan Muara Sungai Tapak Semarang berkisar antara 6,8 - 6,9. Rata-rata nlai suhu di Perairan Muara Sungai Tapak Semarang berkisar antara $30^{\circ} \mathrm{C}-33^{\circ} \mathrm{C}$, sedangkan rata-rata nilai kecerahan di Perairan Muara Sungai Tapak Semarang berkisar antara 0,2 m - 0,7 m. Menurut Poedjirahajoe et al., (2017), kualitas perairan berdasarkan parameter perairan seperti $\mathrm{pH}$ yang berkisar dalam nilai 6,833 - 6,987 masih pada kisaran baik bagi vegetasi mangrove dan biota perairan dengan salinitas yang masih dalam rentang baku mutu perairan mangrove yaitu 38 ppt. Sesuai Keputusan Menteri Lingkungan Hidup No. 51 Tahun 2004, suhu dan DO di Perairan Muara Sungai Tapak Semarang masih dalam rentang baku mutu, yaitu $28{ }^{\circ} \mathrm{C}-33^{\circ} \mathrm{C}$ dengan DO berkisar antara nilai $8,310 \mathrm{mg} / \mathrm{L}-9,260 \mathrm{mg} / \mathrm{L}$. 
Tabel 1. Kualitas Perairan Muara Sungai Tapak Semarang

\begin{tabular}{ccccccc}
\hline No & Stasiun & $\begin{array}{c}\text { Salinitas } \\
(\mathrm{ppt})\end{array}$ & $\begin{array}{c}\mathrm{DO} \\
(\mathrm{mg} / \mathrm{L})\end{array}$ & $\mathrm{pH}$ & Suhu $\left({ }^{\circ} \mathrm{C}\right)$ & $\begin{array}{c}\text { Kecerahan } \\
(\mathrm{m})\end{array}$ \\
\hline \multirow{3}{*}{1} & & 30 & 8,27 & 6,1 & 30 & 0,3 \\
& 1 & 34 & 8,37 & 6,1 & 30 & 0,3 \\
& & 00 & 8,29 & 6,0 & 30 & 0,31 \\
& Rata-rata & 31,333 & 8,310 & 6,067 & 30,000 & 0,303
\end{tabular}

\begin{tabular}{|c|c|c|c|c|c|}
\hline \multirow{3}{*}{ 2 } & 30 & 8,7 & 6,1 & 33,6 & 0,6 \\
\hline & 31 & 8,22 & 6,1 & 32 & 0,59 \\
\hline & 30 & 8,27 & 6,2 & 32 & 0,6 \\
\hline Rata-rata & 30,333 & 8,397 & 6,133 & 32533 & 0,597 \\
\hline
\end{tabular}

\begin{tabular}{ccccccc} 
& & 40 & 9,01 & 6,8 & 32 & 0,65 \\
3 & 3 & 40 & 8,61 & 6,8 & 31 & 0,64 \\
& & 41 & 8,6 & 6,8 & 32 & 0,66 \\
& \multirow{2}{*}{ Rata-rata } & 40,333 & 8,740 & 6,800 & 31,667 & 0,650
\end{tabular}

\begin{tabular}{ccccccc} 
& & 40 & 8,8 & 6,9 & 33 & 0,3 \\
$4 \quad 4$ & 41 & 8,66 & 6,8 & 33 & 0,28 \\
& & 40 & 8,76 & 6,9 & 32 & 0,28 \\
& \multirow{2}{*}{ Rata-rata } & 40,333 & 8,740 & 6,867 & 32,667 & 0,287
\end{tabular}

\begin{tabular}{ccccccc}
5 & & 40 & 8,65 & 6,9 & 33,3 & 0,25 \\
& 5 & 40 & 8,61 & 6,9 & 33,2 & 0,24 \\
& & 41 & 8,65 & 7,01 & 33,1 & 0,25 \\
& \multirow{2}{*}{ Rata-rata } & 40,333 & 8,637 & 6,937 & 33,200 & 0,247
\end{tabular}

\begin{tabular}{ccccccc}
6 & & 39 & 8,62 & 6,9 & 33,5 & 0,35 \\
& 6 & 40 & 8,52 & 6,8 & 33,5 & 0,32 \\
& & 39 & 8,29 & 6,8 & 33,2 & 0,32 \\
& \multirow{2}{*}{ Rata-rata } & 39,333 & 8,477 & 6,833 & 33,400 & 0,330
\end{tabular}

\begin{tabular}{ccccccc}
7 & & 39 & 8,78 & 7,01 & 32,8 & 0,6 \\
& 7 & 39 & 8,63 & 7,01 & 32,7 & 0,55 \\
& & 40 & 8,56 & 6,9 & 32,9 & 0,6 \\
& \multirow{2}{*}{ Rata-rata } & 39,333 & 8,657 & 6,973 & 32,800 & 0,583
\end{tabular}

\begin{tabular}{ccccccc}
8 & & 38 & 9,23 & 7,03 & 32,3 & 0,8 \\
& 8 & 40 & 9,22 & 7,03 & 31,7 & 0,75 \\
& & 39 & 9,33 & 6,9 & 31,3 & 0,75 \\
& \multirow{2}{*}{ Rata-rata } & 39,000 & 9,260 & 6,987 & 31,767 & 0,767
\end{tabular}




\section{B. Faktor Oseanografi}

Data faktor oseanografi yang diambil meliputi kecepatan angin, arah angin dan kecepatan arus. Data ini digunakan sebagai data sekunder sebagai data pendukung yang digunakan dalam penelitian mengenai 'Analisis Kandungan Pencemar Deterjen dan Kualitas Air di Perairan Muara Sungai Tapak, Semarang. Data faktor oseanografi dapat dilihat pada Tabel 2.

Tabel 2. Faktor Oseanografi Perairan Muara Sungai Tapak Semarang

\begin{tabular}{|c|c|c|c|c|}
\hline No & Stasiun & $\begin{array}{c}\text { Kecepatan } \\
\text { Angin }(\mathrm{m} / \mathrm{s})\end{array}$ & $\begin{array}{c}\text { Arah Angin } \\
\left({ }^{\circ}\right)\end{array}$ & $\begin{array}{l}\text { Kecepatan } \\
\text { Arus }(\mathrm{m} / \mathrm{s})\end{array}$ \\
\hline \multirow{4}{*}{1} & & 0,3 & $290 \mathrm{BL}$ & 0,1 \\
\hline & 1 & 0,2 & $298 \mathrm{BL}$ & 0,1 \\
\hline & & 0,2 & $295 \mathrm{BL}$ & 0,1 \\
\hline & Rata-rata & 0,233 & - & 0,1000 \\
\hline \multirow{4}{*}{2} & & 1,5 & $291 \mathrm{BL}$ & 0,1 \\
\hline & 2 & 1,1 & $292 \mathrm{BL}$ & 0,1 \\
\hline & & 1,2 & $293 \mathrm{BL}$ & 0,2 \\
\hline & Rata-rata & 1,267 & - & 0,133 \\
\hline \multirow{4}{*}{3} & & 3,1 & $294 \mathrm{BL}$ & 0,1 \\
\hline & 3 & 3,5 & $310 \mathrm{BL}$ & 0,1 \\
\hline & & 3,4 & $311 \mathrm{BL}$ & 0,1 \\
\hline & Rata-rata & 3,333 & - & 0,100 \\
\hline \multirow{4}{*}{4} & & 2,9 & $310 \mathrm{BL}$ & 0,1 \\
\hline & 4 & 3,1 & $314 \mathrm{BL}$ & 0,1 \\
\hline & & 2,8 & $309 \mathrm{BL}$ & 0,1 \\
\hline & Rata-rata & 2,933 & - & 0,100 \\
\hline \multirow{4}{*}{5} & & 2,9 & $325 \mathrm{BL}$ & 0,1 \\
\hline & 5 & 3,7 & $305 \mathrm{BL}$ & 0,1 \\
\hline & & 4 & $295 \mathrm{BL}$ & 0,1 \\
\hline & Rata-rata & 3,533 & - & 0,100 \\
\hline \multirow{4}{*}{6} & & 3,9 & $306 \mathrm{BL}$ & 0,1 \\
\hline & 6 & 4,5 & $305 \mathrm{BL}$ & 0,2 \\
\hline & & 3,5 & $322 \mathrm{BL}$ & 0,2 \\
\hline & Rata-rata & 3,967 & - & 0,167 \\
\hline
\end{tabular}

$\begin{array}{llll}7 & 4,4 & 320 \mathrm{BL} & 0,2 \\ & 3,8 & 304 \mathrm{BL} & 0,3 \\ & 3,6 & 296 \mathrm{BL} & 0,2\end{array}$




\begin{tabular}{ccccc}
\hline No & Stasiun & $\begin{array}{c}\text { Kecepatan } \\
\text { Angin }(\mathrm{m} / \mathrm{s})\end{array}$ & $\begin{array}{c}\text { Arah Angin } \\
\left({ }^{\circ}\right)\end{array}$ & $\begin{array}{c}\text { Kecepatan } \\
\text { Arus }(\mathrm{m} / \mathrm{s})\end{array}$ \\
\hline \multirow{6}{*}{8} & Rata-rata & 3,933 & - & 0,233 \\
& & & & \\
& & 3,4 & $328 \mathrm{BL}$ & 0,2 \\
& & 2,8 & $301 \mathrm{BL}$ & 0,1 \\
& Rata-rata & 3,067 & $333 \mathrm{BL}$ & 0,1 \\
\hline
\end{tabular}

Tabel 2. menyajikan mengenai kondisi faktor oseanografi yang terdapat Perairan Muara Tapak, Semarang pada setiap stasiun yang digunakan atau diamati. Perairan Muara Sungai Tapak, Semarang memiliki kecepatan arus yang relatif rendah yang memiliki nilai rata-rata sebesar $0,100 \mathrm{~m} / \mathrm{s}-0,233 \mathrm{~m} / \mathrm{s}$ dari stasiun 1 sampai dengan stasiun 8 dengan kecepatan angin yang memiliki nilai rata-rata sebesar $0,233 \mathrm{~m} / \mathrm{s}-3,967 \mathrm{~m} / \mathrm{s}$. Menurut penelitian Riyandari (2017), rendahnya kecepatan arus ini diduga dipengaruhi oleh keberadaan mangrove yang berfungsi sebagai penahan gelombang dan arus. Arus berperan penting dalam penyebaran masukan deterjen ke dalam perairan. Semakin tinggi arus, maka penyebaran masukan deterjen ke perairan akan semakin cepat menuju laut. Namun, dikarenakan Perairan Muara Sungai Tapak, Semarang memiliki kecepatan arus yang relatif rendah, maka konsentrasi deterjen lebih banyak ditemukan di badan sungai yang dalam penelitian ini adalah stasiun 1 dan stasiun 2 .

\section{Indeks Kualitas Air}

Indeks Kualitas Air (IKA) dihitung dengan menggunakan persamaan Altansukh dan Davaa (2011) untuk mengetahui tingkat dan kelas kualitas perairan yang dapat dilihat pada Tabel 3.

Tabel 3. Indeks Kualitas Air

\begin{tabular}{cccccccc}
\hline Stasiun & $\begin{array}{c}\text { Salinitas } \\
(\mathrm{ppt})\end{array}$ & $\begin{array}{c}\mathrm{DO} \\
(\mathrm{mg} / \mathrm{L})\end{array}$ & $\mathrm{pH}$ & $\begin{array}{c}\text { Suhu } \\
\left({ }^{\circ} \mathrm{C}\right)\end{array}$ & Jumlah & Tingkat & Kelas \\
\hline 1 & 0,307 & 0,554 & 0,327 & 0,357 & 1,545 & 3 & Tercemar ringan \\
2 & 0,297 & 0,559 & 0,325 & 0,387 & 1,596 & 3 & Tercemar ringan \\
3 & 0,395 & 0,583 & 0,322 & 0,377 & 1,679 & 3 & Tercemar ringan \\
4 & 0,395 & 0,583 & 0,327 & 0,389 & 1,694 & 3 & Tercemar ringan \\
5 & 0,395 & 0,576 & 0,330 & 0,395 & 1,697 & 3 & Tercemar ringan \\
6 & 0,385 & 0,565 & 0,325 & 0,398 & 1,674 & 3 & Tercemar ringan \\
7 & 0,385 & 0,577 & 0,332 & 0,390 & 1,685 & 3 & Tercemar ringan \\
8 & 0,382 & 0,617 & 0,333 & 0,379 & 1,711 & 3 & Tercemar ringan \\
\hline
\end{tabular}

Tabel 3. menyajikan kondisi kualitas air di Perairan Muara Sungai Tapak Semarang setelah dilakukan perhitungan dengan menggunakan persamaan Altansukh dan Davaa (2011) menggunakan data lapangan yang diperoleh, yaitu salinitas, DO, pH dan suhu. Indeks Kualitas Air (IKA) diperoleh berdasarkan pendekatan perhitungan parameter perairan. Menurut Altansukh dan Davaa (2011) dalam Marganingrum (2013), apabila nilai IKA dalam rentang 0,90 $\leq$ IKA $\leq 2,49$, maka perairan dalam keadaan tingkat 3 dengan kelas tercemar ringan. Nilai rentang IKA pada stasiun 1 sampai stasiun 8 berkisar antara 1,627 - 1,710. Dengan kata lain, kualitas air Perairan Muara Sungai Tapak, Semarang dilihat dari nilai IKA termasuk kedalam perairan yang mengalami pencemaran ringan. Perairan yang mengalami pencemaran ringan tidak sesuai untuk minum dan untuk pertanian. Namun, apabila akan 
digunakan untuk minum dan keperluan pertanian, perlu diolah terlebih dahulu. Sedangkan penggunaan untuk rekreasi dan peternakan tidak perlu diolah.

\section{Indeks Pencemaran}

Indeks Pencemaran (IP) dihitung dengan menggunakan persamaan yang sesuai dengan Keputusan Menteri Lingkungan Hidup No. 115 Tahun 2003 Tentang Status Mutu Air untuk mengetahui tingkat kecemaran suatu perairan yang dapat dilihat pada Tabel 4 .

Tabel 4. Indeks Pencemaran

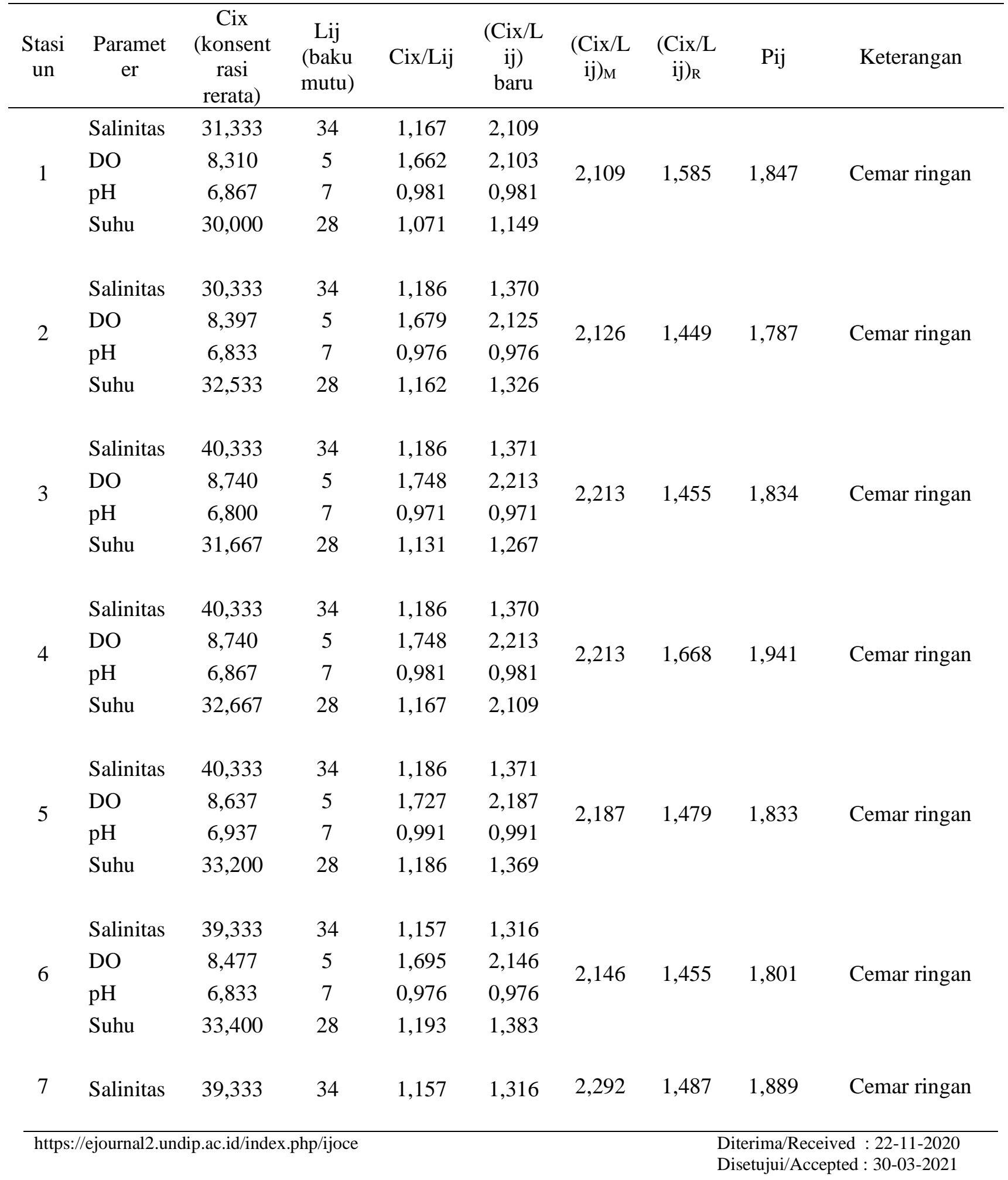




\begin{tabular}{llcccccccc}
\hline $\begin{array}{c}\text { Stasi } \\
\text { un }\end{array}$ & $\begin{array}{c}\text { Paramet } \\
\text { er }\end{array}$ & $\begin{array}{c}\text { Cix } \\
\text { (konsent } \\
\text { rasi } \\
\text { rerata) }\end{array}$ & $\begin{array}{c}\text { Lij } \\
(\text { baku } \\
\text { mutu })\end{array}$ & Cix/Lij & $\begin{array}{c}\text { (Cix/L } \\
\text { ij) } \\
\text { baru }\end{array}$ & $\begin{array}{c}(\mathrm{Cix} / \mathrm{L} \\
\mathrm{ij})_{\mathrm{M}}\end{array}$ & $\begin{array}{c}(\mathrm{Cix} / \mathrm{L} \\
\mathrm{ij})_{\mathrm{R}}\end{array}$ & Pij & Keterangan \\
\hline & DO & 8,657 & 5 & 1,731 & 2,292 & & & & \\
& pH & 6,973 & 7 & 0,996 & 0,996 & & & & \\
& Suhu & 32,800 & 28 & 1,171 & 1,343 & & & & \\
& & & & & & & & & \\
& Salinitas & 39,000 & 34 & 1,147 & 1,838 & & & & \\
8 & DO & 9,260 & 5 & 1,852 & 2,338 & 2,338 & 1,612 & 1,975 & Cemar ringan \\
& pH & 6,987 & 7 & 0,998 & 0,998 & & & & \\
& Suhu & 31,767 & 28 & 1,134 & 1,274 & & & & \\
\hline
\end{tabular}

Tabel 4. menyajikan kondisi Indeks Pencemaran yang dihitung dengan menggunakan persamaan yang berdasarkan Keputusan Menteri Lingkungan Hidup No. 115 Tahun 2003 Tentang Status Mutu Air untuk mengetahui tingkat kecemaran suatu perairan dengan menggunakan data kualitas perairan yang diambil, yaitu salinitas, DO, pH dan suhu. Indeks Pencemaran (IP) diperoleh berdasarkan pendekatan perhitungan parameter perairan. Menurut Keputusan Menteri Lingkungan Hidup No. 115 Tahun 2003, tingkat kualitas perairan dengan nilai 1,1-5,0 termasuk kedalam perairan yang mengalami pencemaran ringan. Nilai IP dalam penelitian ini memiliki rentang nilai sebesar 1,787 - 1,975 dari stasiun 1 sampai stasiun 8. Oleh karena itu, dapat dikatakan bahwa perairan muara Sungai Tapak Semarang mengalami pencemaran ringan berdasarkan nilai Indeks Pencemaran.

\section{E. Analisis Deterjen MBAS}

Perhitungan konsentrasi deterjen dilakukan di Balai Besar Teknologi Pencegah Pencemaran Industri (BBTPPI) dengan metode APHA-AWWA-WEF-5540-C-2005 dapat dilihat pada Tabel 5. berikut ini:

Tabel 5. Hasil Pengujian

\begin{tabular}{clccc}
\hline No & Parameter Uji & Satuan & Hasil Uji & Metode Uji \\
\hline 1 & MBAS & $\mathrm{mg} / \mathrm{L}$ & 0,026 & APHA 22nd, 5540.C: 2012 \\
2 & MBAS & $\mathrm{mg} / \mathrm{L}$ & 0,017 & APHA 22nd, 5540.C: 2012 \\
3 & MBAS & $\mathrm{mg} / \mathrm{L}$ & $<0,010$ & APHA 22nd, 5540.C: 2012 \\
4 & MBAS & $\mathrm{mg} / \mathrm{L}$ & $<0,010$ & APHA 22nd, 5540.C: 2012 \\
5 & MBAS & $\mathrm{mg} / \mathrm{L}$ & $<0,010$ & APHA 22nd, 5540.C: 2012 \\
6 & MBAS & $\mathrm{mg} / \mathrm{L}$ & $<0,010$ & APHA 22nd, 5540.C: 2012 \\
7 & MBAS & $\mathrm{mg} / \mathrm{L}$ & $<0,010$ & APHA 22nd, 5540.C: 2012 \\
8 & MBAS & $\mathrm{mg} / \mathrm{L}$ & $<0,010$ & APHA 22nd, 5540.C: 2012 \\
\hline
\end{tabular}

Sumber: Balai Besar Teknologi Pencegah Pencemaran Industri (BBTPPI), Semarang, Jawa Tengah

Tabel 5. menyajikan data mengenai hasil pengujian MBAS atau kandungan deterjen di Perairan Muara Sungai Tapak Semarang. Hasil nilai MBAS tertinggi sebesar $0,026 \mathrm{mg} / \mathrm{L}$ di stasiun 1 yang terletak di badan sungai. Sedangkan nilai MBAS sebesar 0,017 $\mathrm{mg} / \mathrm{L}$ terletak di stasiun 2 yang terletak di badan sungai. Sedangkan pada stasiun $3-8$, hasil MBAS yang diperoleh adalah $<0,010 \mathrm{mg} / \mathrm{L}$ dikarenakan kandungan deterjen di perairan yang terlalu kecil sehingga berada di bawah limit detection alat yang digunakan. 


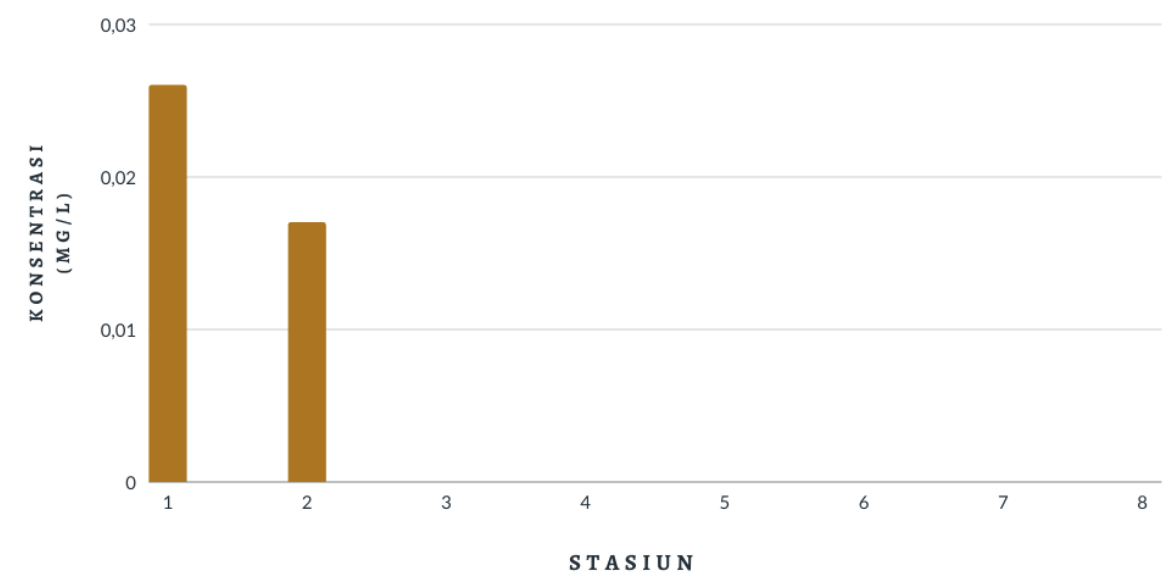

Gambar 2. Hasil Uji Konsentrasi Deterjen di Perairan Muara Sungai Tapak, Semarang

Masukan bahan pencemar deterjen ke dalam perairan, dapat menyebabkan pencemaran dalam perairan. Hal ini dapat dilihat melalui penelitian Dubinzky (2004) yang menyebutkan deterjen anionik yang mengandung Linear Alkylbenzen Sulfonat (LAS) seperti Natrium Dodecyl Sulfat (SDS) menyebabkan perairan pantai Laut Merah mengalami penurunan kemampuan filtrasi dan merusak sel insang kerang Tapes philippinarum serta menurunkan kemampuan alga dalam melakukan fotosintesis. Keberadaan deterjen di perairan, walaupun dalam jumlah kecil dapat memberikan dampak negatif bagi ikan (Sastrawijaya, 2009).

Konsentrasi deterjen di Perairan Sungai Tapak pada stasiun 1 memiliki nilai sebesar 0,026 mg/L dan pada stasiun 2 yang memiliki nilai sebesar $0,017 \mathrm{mg} / \mathrm{L}$ yang terletak di badan sungai. Pada stasiun 3 sampai stasiun 8 pada penelitian ini, konsentrasi deterjen memiliki nilai sebesar $<0,010 \mathrm{mg} / \mathrm{L}$. Nilai konsentrasi deterjen di Perairan Muara Sungai Tapak Semarang yang paling rendah adalah $<0,010 \mathrm{mg} / \mathrm{L}$ dan yang tinggi adalah $0,026 \mathrm{mg} / \mathrm{L}$. Hasil penelitian menunjukkan bahwa konsentrasi deterjen di stasiun 1 sebesar $0,026 \mathrm{mg} / \mathrm{L}$ dan di stasiun 2 sebesar $0,017 \mathrm{mg} / \mathrm{L}$ lebih besar dibandingkan konsentrasi deterjen di stasiun 3 sampai 8 dikarenakan pada stasiun 1 dan 2 berada tepat di dekat dengan saluran pembuangan yang terdapat beberapa sampah plastik. Hal ini sesuai dengan penelitian Sari et al., (2016) yang menyebutkan bahwa Sungai Banjir Kanal Barat memiliki konsentrasi deterjen sebesar 0,05 mg/L - 0,62 $\mathrm{mg} / \mathrm{L}$ yang lebih besar jika dibandingkan dengan penelitian ini, dikarenakan penelitian tersebut berada tepat di dekat saluran pembuangan. Gambar 2. menyajikan diagram batang dari hasil uji konsentrasi deterjen di Perairan Muara Sungai Tapak, Semarang.

Hasil penelitian menunjukkan bahwa konsentrasi deterjen di stasiun 3 sampai 8 memiliki nilai sebesar <0,010. Hal ini dapat disebabkan konsentrasi deterjen di stasiun 3 sampai 8 terlalu kecil, sehingga tidak dapat terdeteksi oleh alat yang digunakan, yaitu spektrofotometer. Selain itu, rendahnya konsentrasi deterjen di stasiun 3 sampai 8 dapat dipengaruhi oleh keberadaan mangrove. Hal ini dikarenakan Perairan Muara Sungai Tapak Semarang merupakan wilayah mangrove. Pada saat melakukan proses fotosintesis, mangrove menyerap $\mathrm{CO}_{2}$ dan $\mathrm{H}_{2} \mathrm{O}$ dengan bantuan sinar matahari yang kemudian diubah menjadi glukosa. Pada proses fotosintesis, mangrove mengubah karbon anorganik $\left(\mathrm{CO}_{2}\right)$ menjadi bahan organik kompleks. Selain untuk proses fotosintesis, mangrove menyimpan $\mathrm{CO}_{2}$ kedalam stok biomass baik di akar, batang maupun daun sehingga akar mangrove memiliki banyak kandungan humus dan membentuk bahan organik kompleks. Sedangkan materi deterjen yang keluar dari saluran pembuangan air menuju perairan tidak mengalami pemecahan saturasi, sehingga ABS (Alkyl Benzene Sulfonat) yang merupakan salah satu kandungan dari deterjen masih dalam bentuk konsentrasi kompleks yang kemudian terikat dengan bahan organik yang terdapat di akar mangrove sehingga menjadi molekul kompleks yang lebih berat dan mengendap di dasar perairan. Sehingga dapat dikatakan bahwa, kandungan deterjen telah mengendap di dasar perairan. 
Hasil penelitian menunjukkan bahwa konsentrasi deterjen di Perairan Muara Tapak Semarang berada dalam rentang nilai $<0,010 \mathrm{mg} / \mathrm{L}-0,026 \mathrm{mg} / \mathrm{L}$, sedangkan menurut Peraturan Pemerintah Nomor 82 Tahun 2001 Tentang Pengelolaan Kualitas Air dan Pengendalian Pencemaran Air, baku mutu deterjen di perairan adalah $200 \mathrm{ug} / \mathrm{L}$ atau setara dengan $0,2 \mathrm{mg} / \mathrm{L}$. Dapat dikatakan bahwa nilai kandungan deterjen di perairan muara Sungai Tapak masih sangat rendah. Rendahnya konsentrasi deterjen di Perairan Muara Sungai Tapak Semarang juga dapat disebabkan oleh keberadaan mangrove di muara Sungai Tapak. Hal ini karena mangrove berfungsi sebagai biofilter (Tam dan Wong, 1996).

\section{KESIMPULAN}

Kesimpulan yang dapat diperoleh adalah:

1. Konsentrasi deterjen di Perairan Muara Sungai Tapak Semarang di stasiun 1 sebesar 0,026 mg/L, di stasiun 2 sebesar $0,017 \mathrm{mg} / \mathrm{L}$ dan pada stasiun 3 sampai 8 memiliki konsentrasi deterjen sebesar $<0,010 \mathrm{mg} / \mathrm{L}$. Berdasarkan Peraturan Pemerintah Nomor 82 Tahun 2001 Tentang Pengelolaan Kualitas Air dan Pengendalian Pencemaran Air, baku mutu deterjen di perairan adalah $200 \mathrm{ug} / \mathrm{L}$ atau setara dengan $0,2 \mathrm{mg} / \mathrm{L}$, sehingga dapat dikatakan bahwa nilai kandungan deterjen di perairan muara Sungai Tapak masih sangat rendah. Nilai Indeks Kualitas Air (IKA) di Perairan Muara Sungai Tapak Semarang berkisar antara 1,627 - 1,710 termasuk kedalam perairan yang mengalami pencemaran ringan. Nilai Indeks Pencemaran (IP) di Perairan Muara Sungai Tapak Semarang berkisar 1,787 1,975 yang termasuk mengalami pencemaran ringan.

2. Kualitas perairan berdasarkan parameter perairan seperti $\mathrm{pH}$ yang berkisar dalam nilai $6,833-6,987$ masih pada kisaran baik bagi vegetasi mangrove dan biota perairan dan salinitas yang masih dalam rentang baku mutu perairan mangrove yaitu 38 ppt. Menurut Keputusan Menteri Lingkungan Hidup No. 51 Tahun 2004, suhu di Perairan Muara Sungai Tapak Semarang masih dalam rentang baku mutu, yaitu $28^{\circ} \mathrm{C}-33^{\circ} \mathrm{C}$. Nilai DO di juga masih dalam rentang baku mutu, yaitu $8,310 \mathrm{mg} / \mathrm{L}-$ $9,260 \mathrm{mg} / \mathrm{L}$ dengan baku mutu $\mathrm{DO}>5 \mathrm{mg} / \mathrm{L}$.

\section{DAFTAR PUSTAKA}

Abrianto, F. dan L.M Jaelani. 2016. Evaluasi Pengukuran Angin dan Arus Laut pada Data Sentinel-1, Data BMKG, dan Data In Situ (Studi Kasus: Perarian Tenggara Sumenep). Jurnal Teknik ITS Vol. 5 (2): 1-2

Altansukh, A. and G. Davaa. 2011. Application of Index Analysis to Evaluate The Water Quality of The Tuul River in Mongolia. Journal of Water Resources and Protection Vol 3: 398-414

APHA. 1992. Standard Methods for The Examination of Water and Wastewater. 18 th ED. American Public Health Association. Washington DC

Askar, Surayah. 1999. Penerapan Statistika Secara Sederhana di Laboratorium Kimia Analitik. Jurnal Lokakarya Fungsional Non Peneliti 1999. Balai Peneliti Ternak. Bogor

Boyd. C.E. 1988. Water Quality in Warmwater Fish Pond. Fourth Printing. Auburn University Agricultral Experiment Stasion. Alabama. USA

Dubinsky, Z. 2004. Distribution and Biological Effect of Detergent in The Red Sea. IET Project No. B1. http://www/iui/eilat.ac.il/Report\%0B doc

Edward dan A.T. Subadya. 1994. Kandungan Deterjen Anionik di Teluk Ambon. Jurnal Ilmu Pengetahuan dan Teknologi

Effendi, H. 2003. Telaah Kualitas Air Bagi Pengelolaan Sumber Daya dan Lingkungan Perairan. Yogyakarta Kanisius. Yogyakarta

Iqbal, H. 2004. Analisis Data Penelitian dengan Statistik. Penerbit Bumi Aksara. Bandung

Keputusan Menteri Lingkungan Hidup No. 51 Tahun 1995 tentang Baku Mutu Limbah Cair Bagi Kegiatan Industri. Menteri Negara Lingkungan Hidup

Keputusan Menteri Lingkungan Hidup No. 115 Tahun 2003 tentang Pedoman Penentuan Status Mutu Air. Departemen Lingkungan Hidup. Pemerintah Negara Republik Indonesia

Kantasubrata, J. 2008. Jaminan Mutu Data Hasil Pengujian: Kontrol Sampel dan Aplikasinya. RC Chem Learning Centre. Bandung 
Manahan, S.E,. 1988. Environmental Chemistry. Fourth Edition. Brooks/Cole Publishing Co., Monterey, California

Manik, J.M. dan Edward. 1987. Sifat-sifat Deterjen dan Dampaknya Terhadap Perairan. Jurnal Oseana Vol 12 (1): 2-9

Marganingrum, D. 2013. Penilaian Mutu Air Sungai dengan Pendekataan Perbesaan Hasil dari Dua Metode Indeks. Buletin Geologi Tata Lingkungan (Bulleting of Environmental Geology) Vol 23 (3): 105-114

Oktaviani A., M. Yusuf, dan L. Maslukah. 2015. Sebaran Konsentrasi Nitrat dan Fosfat di Perairan Muara Sungai Banjir Kanal Barat, Semarang. Jurnal Oseanografi Vol. 4 (1): 1-2

Peraturan Pemerintah No. 82/2001 tentang Pengelolaan Kualitas Air dan Pengendalian Pencemaran Air Poedjirahajoe E., D. Marsono dan F. K. Wardhani. 2017. Penggunaan Principal Component Analysis dalam Distribusi Spasial Vegetasi Mangrove di Pantai Utara Pemalang. Jurnal Ilmu Kehutanan II: $29-42$

Qhomariyah, L dan Yuwono. 2016. Analisa Hubungan antara Pasang Surut Air Laut dengan Sedimentasi yang Terbentuk (Studi Kasus: Dermaga Pelabuhan Petikemas Surabaya). Jurnal Teknik ITS Vol. 5 (1): 1-2

Rao, C.S. 1991. Environmental Pollution Control Engineering. Wiley Eastern Limited. New Dehli

Riyandari, R. 2017. Peran Mangrove Dalam Melindungi Daerah Pesisir Terhadap Gelombang Tsunami. Jurnal Sains dan Teknologi Mitigasi Bencana Vol. 12 (1): 74-80

Sari, D.A., Haeruddin dan S. Rudiyanti. 2016. Analisis Beban Pencemaran Deterjen dan Indeks Kualitas Air di Sungai Banjir Kanal Barat, Semarang dan Hubungannya dengan Kelimpahan Fitoplankton. Diponegoro Journal of Maquares. Vol. 5 (5): 1-4

Sastrawijaya, T. 2009. Pencemaran Lingkungan. Cetakan ke 3. Rineka Cipta. Jakarta

Situmorang, M. 2017. Kimia Lingkungan. Rajawali Press, Depok, $336 \mathrm{hlm}$

Suastuti, Ni. G. A. M. D. A., I. W. Suarsa dan D. K. Putra. 2015. Pengolahan Larutan Deterjen dengan Biofilter Tanaman Kangkungan (Ipomoea crassicaulis) dalam Sistem Batch (Curah) Teraerasi. Jurnal Kimia Vol. 9 (1): 98-104

Sumartini, S., S. Rudiyanti dan Suryanti. 2013. Kualitas Perairan Sungai Seketak Semarang Berdasarkan Komposisi dan Kelimpahan Fitoplankton. Journal Management of Aquatis Resource Vol. 2 (2): $38-45$

Supriyadi, B. 2008. Kajian Waterfront di Semarang (Studi Kasus: Sungai Sungai Tapak). Jurnal Ilmiah Perancangan Kota dan Pemukiman Vol 7 (1): 1-4

Supriyono, E., F. Takashima, dan C.A. Strussman. 1998. Toxicity of Liner Alkybenzene Sulfonate (LAS) to Juvenile Kuruma Shrimp, Panaeus japonicus: A Histopathological Studi on Acuteand Sub-cronic Level. Journal of Tokyo Univercity os Fisheries

Suyasa, W.B. 2015. Pencemaran Air dan Pengolahan Air Limbah. Udayana University Press, Bali, 153 hlm

Tam, N. N. F. Y dan Y.S Wong. 1996. Retention and Distribution of Heavy Metals in Mangrove Soils Receiving Wastewater. Environmental Pollutinon Vol 94 (3): 283-291

Tanjung, R. H. R., B. Hamuna dan Alianto. 2019. Konsentrasi Surfaktan dan Minyak di Perairan Depapre, Kabupaten Jayapura, Provinsi Papua. Buletin Oseanografi Marina Vol. 8 (1): 49-54

Taufik, I. 2006. Pencemaran Deterjen dalam Perairan dan Dampaknya Terhadap Organisme Air. Media Akualtur Vol 1 (1): 25-27

Tungka, A.W., Haeruddin dan C. Ain. 2016. Konsentrasi Nitrat dan Ortofosfat di Muara Sungai Banjir Kanal Barat dan Kaitannya dengan Kelimpahan Fitoplankton Harmful Alga Blooms (HABs). Journal of Fisheries Science and Technology Vol. 12 (1): 40-46

Utomo, W.P., Z.V Nugrajeni., A. Rosyidah., O.M Shafwah., L.K Naashihah.,N. Nurfitria dan I.F Ulfindrayani. 2018. Penurunan Kadar Surfaktan Anionik dan Fosfat dalam Air Limbah Laundry di Kawasan Keputih, Surabaya Menggunakan Karbon Aktif. Akta Kimindo Vol. 3 (1): 128-129

Waluyo, L. 2005. Mikrobiologi Lingkungan. UMM. Malang 
Wolverton, B.C., dan R.C. Mc. Donald. 1975. Application of Vascular Aquatic Plant for Pollutin Removal, Energy and Food Production in a Biological System. NASA Technical Memorandung No. TM-X-72 726, 13 p

Wulandari, F.T dan Ardiansyah. 2012. Pengaruh Deterjen terhadap Mortalitas Benih Ikan Patin sebagai Bahan Pembelajaran Kimia Lingkungan. Jurnal EduSains Vol. 1 (2): 6-7

Yuliani R.L., E. Purwanti dan Y. Pantiwati. 2015. Pengaruh Limbah Deterjen Industri Laundry terhadap Mortalitas dan Indeks Fisiologi Ikan Nila (Oreochromis niloticus). Seminar Nasional XII Pendidikan Biologi FKIP UNS 2015 : 822-823 